\title{
Evaluating Productivity and Cycle Time of Skidding Method with Farm Tractors in Bigadic Forest Enterprise Directorate in Turkey
}

\author{
Tolga Öztürk ${ }^{1 *}$ (D), Merve Gökçe Varsak ${ }^{1}$ (D) Ebru Bilici² $^{(}$ \\ ${ }^{1}$ Istanbul University-C, Faculty of Forestry, Department of Forest Engineering, Istanbul, Turkey \\ ${ }^{2}$ University of Giresun, Dereli Vocational School, Dereli, Giresun, Turkey
}

\begin{abstract}
In Turkey, mechanized harvesting methods have started to be used depending on the recent developments in forest industry, but advanced harvesting machines could not be used in national wide due to high operating cost and terrain conditions. The most common harvesting method is skidding with farm tractors since they are easily accessible and cost efficient. In this study, skidding method by a farm tractor in Bigadic Forest Enterprise Directorate was examined in terms of productivity and cycle time. The factors that affect the machine performance were also evaluated. It was found that the average time measurement of a cycle was 30.75 minute and the average productivity of tractor was found to be $4.75 \mathrm{~m}^{3} /$ hour. The average volume and amount of skidded timber per cycle was about $1.80 \mathrm{~m}^{3}$ and 2 pieces, respectively. Among the factors evaluated in the study area, it was found that skidding distance had a maximum effect on the total cycle time and productivity. Unlike previous time studies, it was found that volume was relatively less effective on the total cycle time. This study revealed that the examination of the total time and productivity in terms of selecting and utilizing the appropriate harvesting technique can yield the best performance of the method.
\end{abstract}

Keywords: Skidding operation, Farm tractor, Time study, Productivity

\section{Introduction}

In timber extraction activities, transportation of forest products from stump to landing is a rather difficult, expensive and time-consuming activity (Eroglu and Acar, 2000). Many countries in the world, farm tractors have been used in forest operations when the terrain conditions and the size of the wood production are not limiting (Akay, 2005). Farm tractors equipped with appropriate forestry attachments are often used for timber extraction because they are versatile and cost effective (Spinelli and Baldini, 1992). Harvest systems consisting of farm tractors are the most popular systems for timber harvesting in Turkish forestry (Öztürk, 2014). Topographical structures restrict ground skidding to slopes of less than 30\% except for short distance (Dykstra and Heinrich, 1996). Farm tractors are used for various forest harvesting tasks including felling, processing, extraction and hauling (Spinelli and Magagnotti, 2012). The high capacity farm tractors offer several potential benefits for forest operations. The highpower tractors can operate on difficult terrain and skid large amount of timber which may increase the productivity of tractors during skidding operations (Kluender et al., 1997). Modified farm tractors play an important role in skidding operation, even after the development of specialized forest articulated tractors (Zecic et al., 2006).

Forest harvesting requires extensive planning, including assessments with multiple criteria analysis (Eker et al, 2006). The most important criteria for suitable planning are productivity and cycle time. Many studies have been done in order to evaluate these criteria in the skidding operation. These studies have revealed that skidding cycle time is affected mainly by skidding distance, terrain conditions, ground slope, and log size (Najafi et al., 2007; Behjou et al., 2008; Gilanipoor et al., 2012; Ghaffariyan et al., 2013; Melemez et al., 2014). In this study, tractor skidding operation was examined to assess the efficiency of the tractor in the areas of Beydag Forest Enterprise Chief (FEC). The objectives were to determine time consumption and productivity $\left(\mathrm{m}^{3} / \mathrm{h}\right)$ of tractor skidding while investigating the factors that affect the tractor performance. 


\section{Material and Methods}

\subsection{Study Site and Data}

Study area is in Beydag FEC within the border of Bigadiç Forest Enterprise, located in northwest Turkey (Figure 1). The total area of Beydağ FEC is 17195 ha. The commercial trees in the FEC are Pinus brutia, Pinus nigra, Juniperus excelsa, Juniperus oxycedrus, Juniperus communis, and Fagus orientalis. This study was applied at compartments of 135 and 136 in Beydağ FEC and skidding operations were executed on either skid road or skid trails. All skidding directions were loaded uphill and unloaded downhill. The terrain of the study area generally had a rough structure. In terms of soil structure, soils in the study area are classified as brown and lime-free forest soils within the humid forest soil belt except some areas in the southeast part of the study area. The study was conducted in Pinus nigra stand. There were two workers and one of them was tractor operator while the other one was carrying out the hooking and unhooking jobs. The work was carried out in May when the soil was in dry condition.

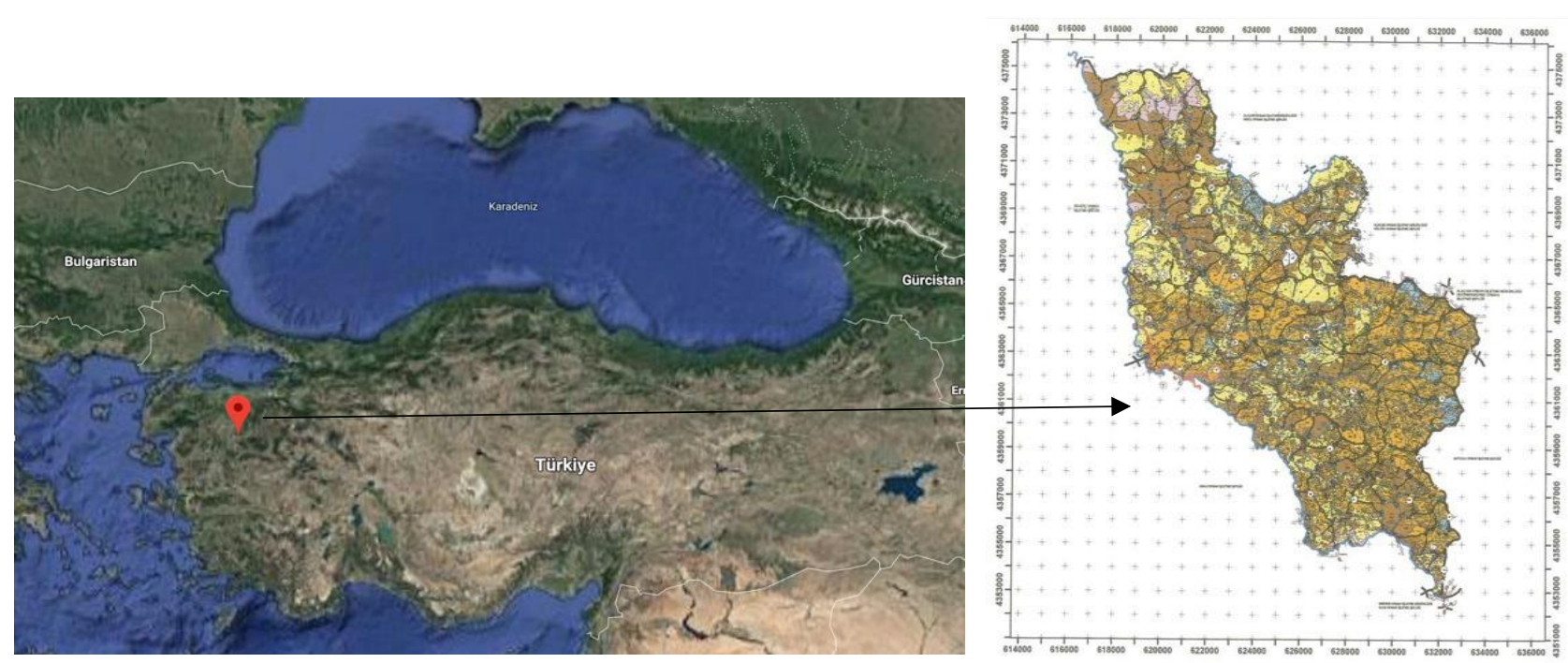

Figure 1 . The study area

In this study, skidding was performed with a Fiat 54 $\mathrm{C}$ tractor which is modified for skidding logs on both skid roads and skid trails. During skidding operation, one end of the dragged timber is in touch with the ground (Figure 2). The technical features of the Fiat 54-C tractor are shown in Table 1.

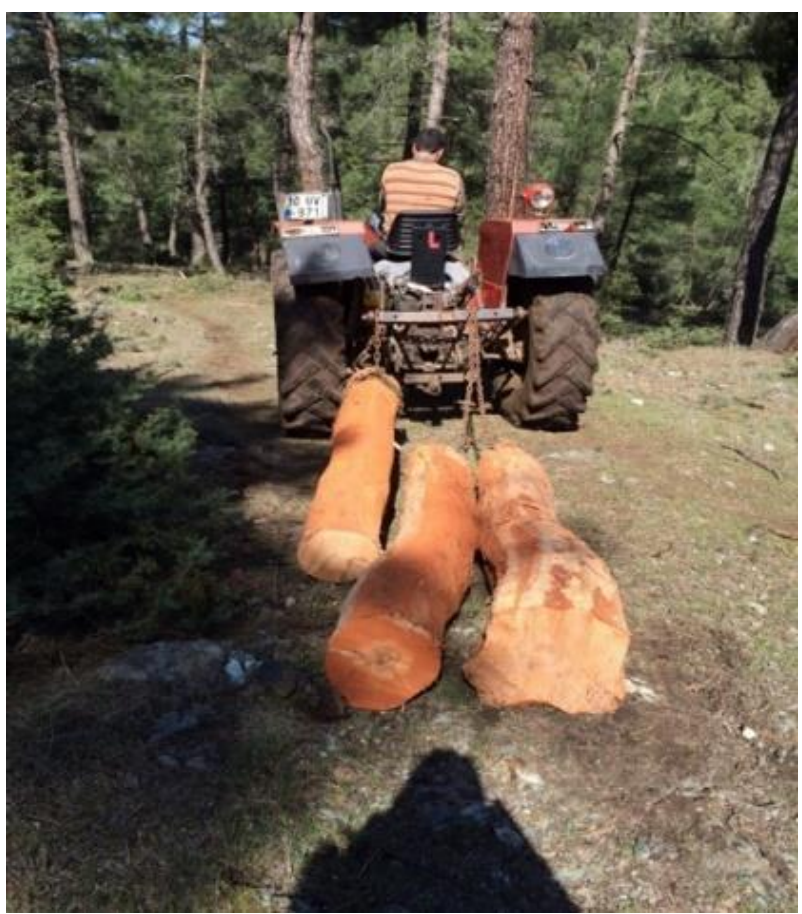

Figure 2. Skidding with Tractor Fiat 54C
Table 1. Fiat 54C Technical Features

\begin{tabular}{ll}
\hline Features & Fiat $54 \mathrm{C}$ \\
\hline Engine & Fiat 8035.06 \\
Weight & $2180 \mathrm{~kg}$ \\
Maximum engine & $55 \mathrm{HP}$ \\
power & \\
Cylinder/volume & $3 / 2710 \mathrm{~cm}$ \\
Engine cycle & $2500 \mathrm{~d} / \mathrm{d}$ \\
Engine type & 4 stroke injection diesel \\
Gas tank & $54 \mathrm{lt}$ \\
Tire size & Front:6.00-16 \\
& Rear:13.6/12.28 (54C- 12) \\
& Front: $6.5-16$ \\
& Rear:14.9/13-28 (54C-13) \\
\hline
\end{tabular}

\subsection{Measurements and Calculations}

The productivity of the farm tractor was evaluated using time study method. Time consumptions of working stages during skidding were measured by repetitive time study method and time data were taken throughout the whole working day. The skidding distance was determined by using a measuring tape and the slope gradient of strip roads was measured by clinometer. The load volume were determined by measuring the diameter and length of each piece of timber under bark by using caliper. 
The time study is an effective research tool used to compare the productivity of harvesting systems considering different factors (McDonald and Fulton, 2005). In this study, the effects of several independent variables including "Skidding distance", "Number of load" and "Load Volume" on the "total cycle time" as a dependent variable were measured. Total of 40 skidding cycles were recorded during farm tractor skidding to evaluate equipment productivity, and identify those variables that are most likely to affect it. All the statistical analyses were performed using the SPSS 21 software.

\section{Results and Discussion}

In this study, timber extraction was conducted with skidding distances varied from $100 \mathrm{~m}$ to $1000 \mathrm{~m}$. The average skidding distance was found to be 385 meters. The skid road width was $2.5 \mathrm{~m}$ and the average slope of skid road was $4 \%$. The most time consuming components of the total skidding time was travel loaded time, followed by travel unloaded time (Figure 3 and Table 2). Rest time, repair time or maintenance time of machine couldn't be included in work cycle, because they were not statistically significant in this study.

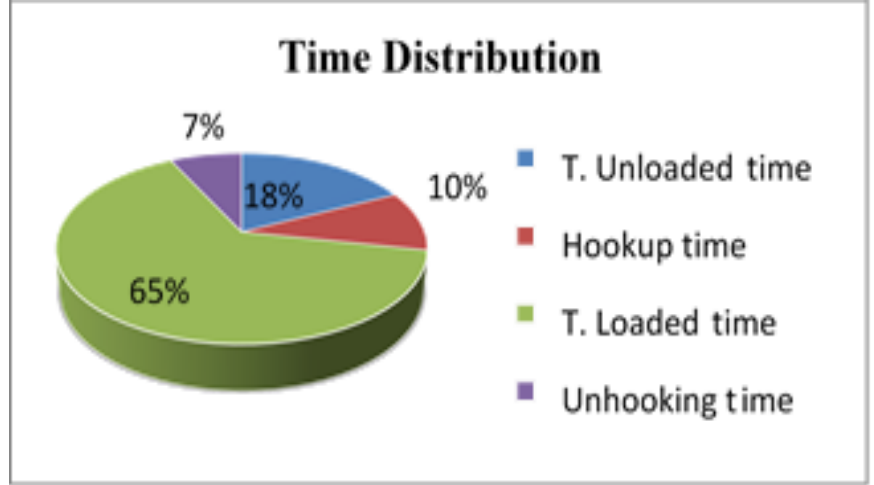

Figure 3. Time distribution in skidding with farm tractor

The average time measurement of a cycle was 30.75 minute and the average productivity of tractor was found to be $4.75 \mathrm{~m}^{3} /$ hour. The average load volume and number of skidded timber was $1.799 \mathrm{~m}^{3}$ and 2, respectively. Factors affecting productivity and total cycle time were investigated using statistical analysis. Firstly, correlation analysis was performed to evaluate the relationship between productivity and two factors including volume value and total time (Table 3 and Table 4).

Table 2. Descriptive statistics of the mean value and standard deviation

\begin{tabular}{lccrc}
\hline & Min & Max & \multicolumn{1}{c}{ Mean } & Std. Deviation \\
\hline Skidding distance $(\mathrm{m})$ & 100 & 1000 & 384.75 & 285.120 \\
Volume $\left(\mathrm{m}^{3}\right)$ & 0.173 & 3.848 & 1.799 & 0.899 \\
Number of load & 1.00 & 3.00 & 2.55 & 0.714 \\
T. Unloaded time $(\mathrm{min})$ & 1.30 & 12.10 & 5.405 & 3.155 \\
Hookup time (min) & 1.00 & 6.20 & 3.087 & 1.728 \\
T. Loaded time $(\mathrm{min})$ & 3.45 & 55 & 19.509 & 14.699 \\
Unhooking time $(\mathrm{min})$ & 0.40 & 4.40 & 2.235 & 1.554 \\
Time $(\mathrm{min})$ & 9.50 & 77.40 & 30.755 & 20.466 \\
Productivity $\left(\mathrm{m}^{3} / \mathrm{h}\right)$ & 0.578 & 12.686 & 4.749 & 3.344 \\
\hline
\end{tabular}

Table 3. Correlation analysis between total time and volume

\begin{tabular}{cccc}
\hline & & Volume & Total Time \\
\hline \multirow{2}{*}{ Volume } & Pearson Correlation & 1 & 0.145 \\
\cline { 2 - 4 } & Sig. (2-tailed) & & 0.373 \\
\cline { 2 - 4 } & $\mathrm{N}$ & 40 & 40 \\
\hline Total Time & Pearson Correlation & 0.145 & 1 \\
\cline { 2 - 4 } & Sig. (2-tailed) & 0.373 & 40 \\
\cline { 2 - 4 } & $\mathrm{N}$ & 40 &
\end{tabular}

Table 4. Correlation analysis between productivity and volume

\begin{tabular}{cccc}
\hline \multirow{3}{*}{ Volume } & & Volume & Productivity \\
\hline & Pearson Correlation & 1 & 0.625 \\
\cline { 2 - 4 } & Sig. (2-tailed) & & 0.000 \\
\cline { 2 - 4 } Productivity & $\mathrm{N}$ & 40 & 40 \\
\cline { 2 - 4 } & Pearson Correlation & 0.625 & 1 \\
\cline { 2 - 4 } & Sig. (2-tailed) & 0.000 & 40 \\
\cline { 2 - 4 }
\end{tabular}


As a result of the analysis, it was found that the volume had a low correlation with total cycle time (0.145), while had a moderate correlation with productivity $(0.625)$. The correlation analysis conducted to evaluate the relationship between the number of load and total cycle time indicated a low correlation with a value of 0.306 (Table 5). The relationship between the number of load and productivity was found to be very low with a value of 0.236 (Table 6).

The ANOVA analysis was conducted to investigate the effect of the number of load on productivity and total cycle time. The number of loads varied between 1 and 3 during the skidding operation. The effect of the number of load for three groups $(1,2$, and 3$)$ was examined in terms of productivity. It was found that there was no statistically significant difference between the three classes since the (p) value being greater than 0.05 (0.228). The number of load and total cycle time of the skidding was found to be unrelated with the values of 0.139 (Table 7 and 8).

Correlation analysis indicated that total time was significantly associated with skidding distance with a value of 0.928 . As the results of second analysis, there was an important inverse relationship between productivity and skidding distance (Table 9 and 10).

Table 5. Correlation analysis between total cycle time and number of load

\begin{tabular}{cccc}
\hline & & Number of load & Total time \\
\hline Number of load & Pearson Correlation & 1 & 0.306 \\
\cline { 2 - 4 } & Sig. (2-tailed) & & 0.055 \\
\cline { 2 - 4 } & $\mathrm{N}$ & 40 & 40 \\
\hline Total time & Pearson Correlation & 0.306 & 1 \\
\cline { 2 - 4 } & Sig. (2-tailed) & 0.055 & 40 \\
\cline { 2 - 4 } & $\mathrm{N}$ & 40 &
\end{tabular}

Table 6. Correlation analysis between productivity and number of load

\begin{tabular}{|c|c|c|c|}
\hline & & Number of load & Productivity \\
\hline \multirow[t]{3}{*}{ Number of load } & Pearson Correlation & 1 & 0.236 \\
\hline & Sig. (2-tailed) & & 0.143 \\
\hline & $\mathrm{N}$ & 40 & 40 \\
\hline \multirow[t]{3}{*}{ Productivity } & Pearson Correlation & 0.236 & 1 \\
\hline & Sig. (2-tailed) & 0.143 & \\
\hline & $\mathrm{N}$ & 40 & 40 \\
\hline
\end{tabular}

Table 7. ANOVA analysis for productivity and number of load

\begin{tabular}{lccccc}
\hline & $\begin{array}{c}\text { Sum of } \\
\text { Squares }\end{array}$ & df & Mean Square & F & Sig. \\
\hline $\begin{array}{l}\text { Between } \\
\text { Groups }\end{array}$ & 33.527 & 2 & 16.763 & 1.541 & 0.228 \\
\hline Within Groups & 402.533 & 37 & 10.879 & & \\
\hline Total & 436.060 & 39 & & & \\
\hline
\end{tabular}

Table 8. ANOVA analysis for total time and number of load

\begin{tabular}{|c|c|c|c|c|c|}
\hline & $\begin{array}{c}\text { Sum of } \\
\text { Squares }\end{array}$ & df & Mean Square & $\mathrm{F}$ & Sig. \\
\hline $\begin{array}{l}\text { Between } \\
\text { Groups }\end{array}$ & 1651.484 & 2 & 825.742 & 2.081 & 0.139 \\
\hline Within Groups & $\begin{array}{c}14683.33 \\
8\end{array}$ & 37 & 396.847 & & \\
\hline Total & $\begin{array}{c}16334.82 \\
2\end{array}$ & 39 & & & \\
\hline
\end{tabular}


Table 9. Correlation analysis between total time and skidding distance

\begin{tabular}{|c|c|c|c|}
\hline & & Skidding Distance & Total time \\
\hline \multirow[t]{3}{*}{ Skidding distance } & Pearson Correlation & 1 & $0.928(* *)$ \\
\hline & Sig. (2-tailed) & & 0.000 \\
\hline & $\mathrm{N}$ & 40 & 40 \\
\hline \multirow[t]{3}{*}{ Total Time } & Pearson Correlation & $0.928(* *)$ & 1 \\
\hline & Sig. (2-tailed) & 0.000 & \\
\hline & $\mathrm{N}$ & 40 & 40 \\
\hline
\end{tabular}

Table 10. Correlation analysis between productivity and skidding distance

\begin{tabular}{|c|c|c|c|}
\hline & & Skidding Distance & Productivity \\
\hline \multirow[t]{3}{*}{ Skidding distance } & Pearson Correlation & 1 & $-0.571(* *)$ \\
\hline & Sig. (2-tailed) & & 0.000 \\
\hline & $\mathrm{N}$ & 40 & 40 \\
\hline \multirow[t]{3}{*}{ Productivity } & Pearson Correlation & $-0.571(* *)$ & 1 \\
\hline & Sig. (2-tailed) & 0.000 & \\
\hline & $\mathrm{N}$ & 40 & 40 \\
\hline
\end{tabular}

The study showed that skidding distance was the highly correlated factor affecting total time and productivity. In order to investigate the effects of various skidding distances, it was grouped into three classes including 0-250 m (1), 251-500 $\mathrm{m} \mathrm{(2)} \mathrm{and} \mathrm{more} \mathrm{than} 500$ $\mathrm{m}$ (3). The ANOVA test was performed to determine if there were any significant differences between the groups (Table 11). It was found that there was a statistically significant difference between the three groups since due to the (p) value (0.000) being less than 0.05 . According to the Post-doc analysis results, there was a significant difference between groups 1 and 2 and between 1 and 3 .

Table 11. ANOVA analysis for skidding distance groups

\begin{tabular}{lccccc}
\hline & $\begin{array}{c}\text { Sum of } \\
\text { Squares }\end{array}$ & df & $\begin{array}{c}\text { Mean } \\
\text { Square }\end{array}$ & F & Sig. \\
\hline $\begin{array}{l}\text { Between } \\
\text { Groups }\end{array}$ & 169.357 & 2 & 84.679 & 11.748 & 0.0000 \\
\hline $\begin{array}{l}\text { Within } \\
\text { Groups }\end{array}$ & 266.703 & 37 & 7.208 & & \\
\hline Total & 436.060 & 39 & & & \\
\hline
\end{tabular}

In a similar study conducted by Naghdi (2004) mentioned that the productivity of skidder was 17.1 $\mathrm{m}^{3} /$ hour. Huyler and LeDoux (1989) determined that the total time per cycle was $34.14 \mathrm{~min}$ for $270 \mathrm{~m}$ skidding distance by Massey Ferguson tractor. In another study conducted in the mountainous area in Black Sea region in Turkey (Öztürk, 2010), it was found that hourly productivity was $11.35 \mathrm{~m}^{3}$ for $140 \mathrm{~m}$ and $7.7 \mathrm{~m}^{3}$ for skidding distance of $320 \mathrm{~m}$. Gülci et al. (2018) conducted the efficiency analysis of a tractor which indicated that the average production rate of the tractor skidding was $5.72 \mathrm{~m}^{3} / \mathrm{hr}$ and $4.30 \mathrm{~m}^{3} / \mathrm{hr}$ for the worksites with $20 \%$ slope and $30 \%$ slope, respectively.
Abeli (1992) indicated that skidding productivity is affected by the number of logs per cycle. However, in this study it was revealed that the system productivity was not strongly influenced by the number of logs per turn. On the other hand, some of studies were indicated that there was a doubt that skidding distance significantly affected skidding cycle time and production rate (Liu, 1993). In a similar study, Gilanipoor et al. (2012) reported that effective independent variables of skidding time were skidding distance and slope of skid trail. The result of this study also showed that the farm tractor productivity was affected by skidding distance.

\section{Conclusions}

In the study, three factors (skidding distance, load volume, number of load) affecting productivity and total time were examined. It was determined that the work stage with maximum amount of time was travel loaded time of the farm tractor. Proportion of travel unloaded time and hookup times were found to be much less. When the effects of the factors were examined, it was found that skidding distance had an important effect on total time and productivity. On the other hand, the volume had the least effect on the total time. However, there was a moderate significant correlation between productivity and volume. The number of load was also found to have a low-grade relationship with productivity and total time. Increasing the average skidding distance during the wood production decreases the efficiency of harvesting equipment. Besides, the cost of skidding increases as the skidding distance increases in harvesting unit. Thus, the forest engineers should plan for shorter skidding distances in order to increase productivity while reducing the cost in timber extraction activities. On the other hand, the skid roads and trails should be located in the form of a network in harvesting unit. 


\section{References}

Abeli W.S., 1992. Optimal road spacing for manual skidding sulkies. Journal of Tropical Forest Science, 6: 8-15.

Akay, A. E., 2005. Using farm tractors in small-scale forest harvesting operations. Journal of Applied Sciences Research, 1(2): 196-199.

Behjou, F.K., Majnounian, B., Namiranian, M., Dvorak, J., 2008. Time study and skidding capacity of the wheeled skidder Timberjack 450c in Caspian forests. J For Sci, 54(4):183-188.

Dykstra, D.P., Heinrich, R., 1996. FAO model code of forest harvesting practice. FAO Publish, Rome, Italy, $85 \mathrm{pp}$.

Eker M., Acar, H.H., 2006. Operational Planning Method For Timber Harvesting, Turkish Journal of Forestry 7 (2): 128-140.

Eroglu, H., Acar, H.H., 2000. The comparison of logging techniques for productivity and ecological aspects in Artvin, Turkey. Journal of Applied Sciences, 7: 1973-1976.

Ghaffariyan, M.R., Naghdi, R., Ghajar, I., Nikooy, M., 2013. Time prediction models and cost evaluation of cut-to-length (CTL) harvesting method in a mountainous forest. Small-Scale Forestry, 12(2): 181-192.

Gilanipoor, N., Najafi, A., Heshmat Alvaezin, S.M., 2012. Productivity and cost of farm tractor skidding. J For Sci, 58(1): 21-26.

Gülci, S., Büyüksakallı, H., Taş, İ., Akay, A.E., 2018. Productivity analysis of timber skidding operation with farm tractor. Eur J Forest Eng, 4(1): 26-32.

Huyler, N.K., Ledoux, C.B., 1989. Small tractors for harvesting fuelwood in low-volume small diameter hardwood stands. COFE, Implementing Techniques for Succesful Forest Operations, August 27 to 30, Idoha, 1989: 61-67.

Kluender, R., Lortz, D., McCoy, W., Stokes, B., Klepac, J., 1997. Productivity of rubber-tired skidders in southern pine forests. Forest Products Journal, 47(11-12): 53-58.

Liu S., Corcoran T.J., 1993. Road and landing spacing under the consideration of surface dimension of road and landing. Journal of Forest Engineering, 5: 49-53

McDonald, T.P., Fulton, J.P., 2005. Automated time study of skidders using global positioning system data. Computers and Electronics in Agriculture, 48: 19-37.

Öztürk, T., 2010. Productivity of new holland farm tractor at beech stands on mountainous areas in black sea region. Forestry Ideas, 16(1): 52-57.

Öztürk, T., 2014. Productivity and cost of rubber - tired tractor in northern pine plantation forest of Turkey. Baltic Forestry, 20 (2): 272-276.

Spinelli, R., Baldini, S., 1992. Productivity and cost analysis of logging arch used with farm tractor in Mediterranean forest skidding operations. Invest. Agrar., Sist. Recur. For., 1(2): 211-221.

Spinelli, R., Magagnotti, N., 2012. Wood extraction with farm tractor and sulky: estimating productivity, cost and energy consumption. Small-Scale Forestry, 11(1):73-85.

Melemez, K., Tunay, M., Emir, T., 2014. A comparison of productivity in five small-scale harvesting systems. Small-Scale Forestry, 13: 35-45.

Naghdi, R., 2004. Study of optimum road density in tree length and cut to length systems. PhD. Thesis, University of Tarbiat Modarres, Faculty of Natural Resources.

Najafi, A., Sobhani, H., Saeed, A., Makhdoom, M., Marvimohajer, M.R., 2007. Time study of skidder HSM 904. J Iran Nat Res., 60(3): 921-930.

Zecic, Z., Krpan, A. P. B., Vukusic, S., 2006. Productivity of $\mathrm{C}$ Holder $870 \mathrm{~F}$ tractor with double drum winch Igland 4002 in thinning beech stands. Croatian Journal of Forest Engineering, 27(1): 4956. 